\title{
Presence of pharmaceutical compounds in groundwater with respect to land use in the vicinity of sampling sites
}

\author{
Anna Kuczyńska \\ Polish Geological Institute - National Research Institute,Hydrogeology and Environmental Geology Program, \\ 4 Rakowiecka Street, 00-975 Warszawa, Poland \\ e-mail: anna.kuczynska@pgi.gov.pl
}

\begin{abstract}
The present paper discusses the results of an analysis of the impact of land use on the distribution of pharmaceuticals in groundwater samples collected during a pilot study of the contents of pharmaceuticals and hormones in groundwater taken from the national groundwater monitoring network of the Polish Geological Institute - National Research Institute. Samples were collected during monitoring campaigns from 160 groundwater monitoring sites in various land use types in 2016 and 2017. Samples were analysed for a total of 34 active substances, including natural and synthetic oestrogen hormones, cardiovascular and respiratory medications, analgesics and anti-inflammatories, antidepressants, antimicrobial drugs and anti-epileptics. Our study confirmed the presence of pharmaceuticals in 53 per cent of groundwater samples taken. Data show variations in the distribution of pharmaceuticals depending on land use type, which can thus be employed in pressure analysis and identification of sources of pollution.
\end{abstract}

Key words: water quality, groundwater pollution, pharmaceuticals, Poland

\section{Introduction}

The presence of pharmaceuticals in groundwater has been widely studied and discussed over the past few years (Seiler et al., 1999; Sacher et al., 2001; Kolpin et al., 2002; Cordy et al., 2004; Verstraeten et al., 2005; Barnes et al., 2008; Zuccato et al., 2008; Loos et al., 2010; Vulliet \& Cren-Olive, 2011; Lapworth et al., 2012; Stuart et al., 2012; Gaffney et al., 2015; Lopez et al., 2015; Lapworth et al., 2019). Their presence is most commonly associated with pollution from communal wastewater (Seiler et al., 1999; Verstraeten et al., 2005) as well as with agriculture because veterinary medicines can often be found in manure, used as a natural fertiliser (Lapworth et al., 2012; Stuart et al., 2012). Pharmaceuticals are one of many substances known as anthropogenic organic compounds that have only recently been recognised as a growing threat to groundwater resources. Their occurrence and fate in the environment are not well understood and mostly not regulated; however, increasingly more studies confirm the growing problem of their presence in both groundwater and surface water. For that reason, pharmaceuticals were one of the first groups of emerging contaminants that have been considered for detailed analysis when developing a methodology for a groundwater watch list for substances of emerging concerns (Lapworth et al., 2019). Such watch list is a consequence of the 2014 review of the EU Groundwater Directive Annexes (Commission Directive 2014/80/EU) during which the need to 
obtain and respond to new information on other substances that pose a potential risk was officially acknowledged. As such the Commission delegated the task of developing such a watch list to expert groups who work under the Common Implementation Strategy for Directive 2000/60/EC.

In Poland, studies of pharmaceutical content in groundwater are not widespread. However, the few research results available have confirmed the validity of their implementation (Caban et al., 2015; Kmiecik et al., 2017a, 2017b; Kuczyńska, 2017; Kuczyńska \& Janica, 2017). In 2016-2017, the Polish Geological Institute - National Research Institute conducted a pilot study of the content of pharmaceuticals in groundwater throughout the country. The first part of the research was carried out on the occasion of implementation of surveillance monitoring in 2016, at the request of the Chief Inspectorate of the Environment (Kuczyńska, 2017). This proved the presence of active pharmaceutical substances in > 60 per cent of 93 samples selected for analytical studies. The study was continued in 2017, albeit to a smaller extent due to budget cuts. In 2017 sampling was carried out during operational and research monitoring at the request of the Chief Inspectorate of the Environment and the National Water Management Board. In both years, sampling was funded by the National Fund for Water Management and Environmental Protection. The costs of laboratory analyses were paid for as part of the PGI-NRI's statutory research scheme that is funded by the Ministry of Science and Higher Education. For the present paper data from the 2-year pilot were analysed together and are presented in the light of land use, together with a comparison with results of other monitoring data.

\section{Methodology}

\subsection{Sampling}

The pilot study on pharmaceutical content in groundwater was undertaken during two sampling campaigns in the years 2016-2017. In 2016 sampling was carried out on the occasion of surveillance monitoring across the entire country, in all groundwater bodies (172). The total number of monitoring boreholes covered during the surveillance campaign was 1,266. Of these, 105 monitoring boreholes were selected for determination of pharmaceuticals. Locations of sampling points were carefully studied to reflect potential pollution sources associated with the proximity to urban agglomerations or rural ar- eas (poor sewage networks, spread of manure), or close to documented outbreaks of pollution, e.g., a cemetery, a hospital, sewage treatment plants, or a short distance from surface water courses. The depth to the water-bearing zone and borehole logs were analysed to ensure that sampling locations could have been exposed particularly to the impact of municipal anthropogenic pressure due to the shallow occurrence of water-bearing horizons, devoid of isolation. During the initial selection, 105 wells were selected to meet the above assumptions, while sampling attempts were made in 98 boreholes. For technical reasons (no possibility of sampling) and random (damage to samples during transport), samples collected in 93 selected locations were analysed. These points were located within an area of 60 groundwater bodies, 98 per cent of which are within porous Quaternary formations. Sixteen out of 60 groundwater bodies covered by this studywere defined at the risk of not achieving environmental goals in river basin management plans for 2016-2021 (Regulation of the Council of Ministers, Dz. U. 2016 poz. 1818, poz. 1911, poz. 1914, poz. 1915, poz. 1917, poz. 1918, poz. 1919, poz. 1929, poz. 1959, poz. 1967).

In 2017 sampling was carried out within the framework of operational and research monitoring. The operational monitoring was done in 392 monitoring boreholes located within 66 groundwater bodies, including 39 GWBs that were defined at the risk of not achieving environmental goals in river basin management plans for 2016-2021 and 27 GWBs were included in the monitoring of nitrate-vulnerable zones 2012-2015. In total 50 sampling points were selected and samples collected from 46 of these. An additional set of 21 samples was collected from a network serving research monitoring that is destined to monitor water quality in areas of potential environmental problems linked with industrial activities or large accumulation of pollution sources such as agglomerations. Again, depth to the water-bearing zone and borehole logs were analysed to ensure that sampling locations could have been particularly exposed to the impact of municipal anthropogenic pressure due to the shallow occurrence of water-bearing horizons, devoid of isolation. In total 67 samples were collected for the 2017 study. There were no duplicate sampling locations over those two years and in both years collections were made between April and October. The total number of samples analysed was 160 .

Water samples were collected in accordance with accreditation rules for the collection of groundwater samples held by the Polish Geological Institute-National Research,and in line with the PN-EN ISO 5667-11:2004P standard. To collect representative 
groundwater samples, monitoring boreholes were cleaned and pumped out using suction pumps prior to water sampling. Temperature stability, $\mathrm{pH}$ and conductivity were monitored in order to confirm the inflow of fresh water from an aquifer to the sampling wells. Depending on the stability of the parameters monitored, the volume of water pumped from wells varied from 3 to 5 volumes of stagnant water. Water samples were collected into three 1-litre bottles of pharmaceutical glass. Bottles and cups were rinsed with water before a water sample was taken. Water was kept under a cork, under which an aluminium foil was placed to protect against sorption of more non-polar analytes. Bottles with water samples were transported to the laboratory in thermal containers equipped with cooling cartridges. Samples were delivered to the laboratory within 24 hours of sampling.

\subsection{Chemical analysis}

The scope of analytical tests included 34 active substances of the following groups of drugs:

- Oestrogenic hormones: estrone, estriol, 17a-ethinylestradiol (EE2), 17ß-estradiol (E2), testosterone;

- $\beta$-blockers (drugs against cardiovascular disease): nadolol (2016), atenolol (2017), metoprolol, pindolol, propranolol;

- $\beta$-agonists (medicines against respiratory diseases): terbutaline, salbutamol;
- Analgesics and anti-inflammatory drugs: diclofenac, ibuprofen, ketoprofen, naproxen, paracetamol, flurbiprofen;

- Antidepressants: imipramine, clomipramine, doxepine (2016 only), amitriptyline (2017 only);

- Antimicrobial agents (sulfonamides and antibiotics): sulfadiazine, sulfadimethoxine, sulfamerazine, sulfamethazine, sulfamethoxazole, sulfapyridine and sulfathiazole, sulfachloropiridazine and trimethoprim, enrofloxacin;

- Anti-epileptics: carbamazepine;

- Caffeine (2017 only).

Chemical analyses were done at the Faculty of Chemistry of the University of Gdańsk in the Laboratory of Analytical and Environmental Monitoring using gas and liquid chromatography (Caban et al., 2012; Borecka et al., 2015; Caban et al., 2015). The sample preparation step included a high-volume solid phase extraction using accelerated extraction discs and derivatisation (GC/MS method only). The final determinations were made using two techniques, depending on the group of drugs. Oestrogenic hormones, $\beta$-blockers, $\beta$-agonists, analgesics and tricyclic antidepressants were determined by gas chromatography coupled with mass spectrometry (GC/MS) in the mode of selected ion monitoring (SIM). Antimicrobial drugs, carbamazepine and caffeine were determined using high-performance liquid chromatography coupled with tandem mass spectrometry (LC-MS/MS) in the MRM recording mode. Quality of results was achieved by instrumental and methodological validation, which

Table 1. Metrological parameters of analytical methods of compounds using GC / MS (SIM) and LC-MS/MS (MRM).

\begin{tabular}{lcrrrrc}
\hline \multicolumn{1}{c}{ Pharmaceuticals } & Year & Range of linearity $\left(\mathrm{ng} / \mathrm{dm}^{3}\right)$ & $\mathrm{MQL}^{2)}\left(\mathrm{ng} / \mathrm{dm}^{3}\right)$ & $\left.\mathrm{R}^{3}\right)$ & $\mathrm{RSD}^{4)}$ & Recovery $^{5}(\%)$ \\
\hline 17alfa-etynyloestradiol (EE2) & 2016 & $10-100$ & 10 & 0.9998 & $3.64-3.45$ & $95.8-109.5$ \\
& 2017 & $5-100$ & 5 & 0.9996 & $2.1-7.3$ & $65.3-110.0$ \\
17beta-estradiol (E2) & 2016 & $5-100$ & 5 & 0.9997 & $0.81-1.62$ & $82.6-109.1$ \\
& 2017 & $5-100$ & 5 & 0.9998 & $5.3-7.7$ & $93.6-113.8$ \\
Amitryptyline & 2017 & $10-100$ & 10 & 0.9999 & $5.0-8.5$ & $95.1-111.5$ \\
Atenolol & 2017 & $1-100$ & 1 & 0.9988 & $1.2-6.4$ & $94.7-102.16$ \\
Diclofenac & 2016 & $5-100$ & 5 & 0.9997 & $0.32-3.23$ & $82.9-100.1$ \\
& 2017 & $5-100$ & 5 & 0.9999 & $5.0-6.9$ & $88.3-111.6$ \\
Doxepine & 2016 & $5-100$ & 5 & 1.0000 & $0.65-1.98$ & $91.6-104.4$ \\
Enrofloxacin & 2016 & $5-100$ & 5 & 0.9997 & $0.82-1.80$ & $83.3-108.9$ \\
& 2017 & $5-100$ & 5 & 0.9998 & $2.47-6.18$ & $95.1-101.7$ \\
Estriol & 2016 & $5-100$ & 5 & 0.9996 & $1.55-3.70$ & $70.6-101.6$ \\
& 2017 & $5-100$ & 5 & 0.9999 & $7.1-13.1$ & $84.8-108.6$ \\
Estrone & $5-100$ & 5 & 0.9998 & $2.92-7.37$ & $84.9-110.5$ \\
& 2016 & $5-100$ & 5 & 0.9993 & $2.0-8.0$ & $87.7-113.9$ \\
Flurbiprofen & 2017 & $5-100$ & 5 & 0.9999 & $1.71-2.97$ & $79.1-115.3$ \\
Ibuprofen & 2016 & $5-100$ & 5 & 0.9998 & $1.4-5.0$ & $89.6-115.6$ \\
& 2017 & $5-100$ & 5 & 0.9991 & $1.60-1.83$ & $81.2-116.6$ \\
\hline
\end{tabular}




\begin{tabular}{|c|c|c|c|c|c|c|}
\hline Pharmaceuticals & Year & Range of linearity ${ }^{1}\left(\mathrm{ng} / \mathrm{dm}^{3}\right)$ & $\mathrm{MQL}^{2)}\left(\mathrm{ng} / \mathrm{dm}^{3}\right)$ & $\mathrm{R}^{3)}$ & $\mathrm{RSD}^{4)}$ & Recovery $^{5}(\%)$ \\
\hline \multirow[t]{2}{*}{ Imipramine } & 2016 & $5-100$ & 5 & 0.9998 & $1.73-6.64$ & 88.1-109.9 \\
\hline & 2017 & $5-100$ & 5 & 0.9993 & $1.8-7.8$ & $80.7-111.9$ \\
\hline \multirow[t]{2}{*}{ Carbamazepine } & 2016 & $1-100$ & 1 & 0.9997 & $1.65-6.21$ & $81.8-108.9$ \\
\hline & 2017 & $1-100$ & 1 & 0.9993 & $0.96-5.68$ & $92.3-103.8$ \\
\hline \multirow[t]{2}{*}{ Ketoprofen } & 2016 & $5-100$ & 5 & 0.9999 & $1.86-4.42$ & $85.1-102.0$ \\
\hline & 2017 & $5-100$ & 5 & 1.0000 & $3.0-8.1$ & $88.0-109.9$ \\
\hline \multirow[t]{2}{*}{ Clomipramine } & 2016 & $10-100$ & 10 & 0.9998 & $1.69-8.01$ & $88.1-106.4$ \\
\hline & 2017 & $10-100$ & 10 & 0.9990 & $5.8-10.6$ & $95.6-113.9$ \\
\hline Caffeine & 2017 & 5-100 & 5 & 1.0000 & $5.12-8.97$ & $80.3-104.6$ \\
\hline \multirow[t]{2}{*}{ Metoprolol } & 2016 & $1-100$ & 1 & 0.9998 & $0.23-6.81$ & 90.9-115.3 \\
\hline & 2017 & $10-100$ & 10 & 0.9890 & $3.9-4.3$ & 96.9-118.1 \\
\hline Nadolol & 2016 & $1-100$ & 1 & 1.0000 & $0.54-4.74$ & $93.6-101.7$ \\
\hline \multirow[t]{2}{*}{ Naproxen } & 2016 & $5-100$ & 5 & 0.9996 & $0.17-3.58$ & 72.9-105.3 \\
\hline & 2017 & $5-100$ & 5 & 0.9999 & $2.4-7.5$ & $89.0-103.4$ \\
\hline \multirow[t]{2}{*}{ Paracetamol } & 2016 & $5-100$ & 5 & 1.0000 & $4.56-8.68$ & 98.4-109.6 \\
\hline & 2017 & $5-100$ & 5 & 0.9999 & $1.6-7.9$ & $86.3-115.2$ \\
\hline \multirow[t]{2}{*}{ Pindolol } & 2016 & $10-100$ & 10 & 0.9998 & $3.26-8.01$ & 83.0-11.1. \\
\hline & 2017 & $10-100$ & 10 & 0.9850 & $4.0-6.8$ & $89.2-137.3$ \\
\hline \multirow[t]{2}{*}{ Propranolol } & 2016 & 5-100 & 5 & 1.0000 & $0.10-3.52$ & $97.7-102.7$ \\
\hline & 2017 & $5-100$ & 5 & 0.9990 & $0.9-7.5$ & $96.5-112.0$ \\
\hline \multirow[t]{2}{*}{ Salbutamol } & 2016 & $5-100$ & 5 & 0.9975 & $1.39-4.77$ & 97.9-121.1 \\
\hline & 2017 & $5-100$ & 5 & 0.9979 & $5.2-6.6$ & $68.3-102.4$ \\
\hline \multirow[t]{2}{*}{ Sulfachloropiridazine } & 2016 & $1-100$ & 1 & 0.9999 & $0.43-5.22$ & $96.7-117.9$ \\
\hline & 2017 & $1-100$ & 1 & 0.9999 & $2.70-7.94$ & $95.5-114.8$ \\
\hline \multirow[t]{2}{*}{ Sulfadiazine } & 2016 & $1-100$ & 1 & 0.9999 & $1.99-5.38$ & $95.6-108.5$ \\
\hline & 2017 & $1-100$ & 1 & 0.9998 & $1.74-5.73$ & $84.8-117.0$ \\
\hline \multirow[t]{2}{*}{ Sulfadimethoxine } & 2016 & $1-100$ & 1 & 0.9998 & $3.66-7.90$ & $91.7-102.2$ \\
\hline & 2017 & $1-100$ & 1 & 1.0000 & $1.45-5.91$ & $97.7-116.5$ \\
\hline \multirow[t]{2}{*}{ Sulfamerazine } & 2016 & $1-100$ & 1 & 0.9998 & $4.08-8.97$ & 89.9-101.9 \\
\hline & 2017 & $1-100$ & 1 & 0.9999 & $2.62-6.45$ & $95.2-112.0$ \\
\hline \multirow[t]{2}{*}{ Sulfamethazine } & 2016 & $1-100$ & 1 & 1.0000 & $3.30-6.76$ & $95.6-100.4$ \\
\hline & 2017 & $1-100$ & 1 & 0.9998 & $1.40-4.26$ & $92.6-102.0$ \\
\hline \multirow[t]{2}{*}{ Sulfamethoxazole } & 2016 & $1-100$ & 1 & 1.0000 & $0.85-8.11$ & $99.1-111.8$ \\
\hline & 2017 & $1-100$ & 1 & 0.9997 & $2.32-5.72$ & $91.4-102.5$ \\
\hline \multirow[t]{2}{*}{ Sulfapiridine } & 2016 & $1-100$ & 1 & 1.0000 & $2.71-8.56$ & $98.8-103.7$ \\
\hline & 2017 & $1-100$ & 1 & 0.9994 & $1.47-4.29$ & $84.3-100.2$ \\
\hline \multirow[t]{2}{*}{ Sulfathiazole } & 2016 & $1-100$ & 1 & 0.9997 & $2.36-6.09$ & $92.7-128.4$ \\
\hline & 2017 & $1-100$ & 1 & 0.9999 & $1.96-6.50$ & 98.9-103.9 \\
\hline \multirow[t]{2}{*}{ Terbutaline } & 2016 & $5-100$ & 5 & 1.0000 & $1.00-2.18$ & $98.4-100.0$ \\
\hline & 2017 & 5-100 & 5 & 0.9998 & $4.0-8.7$ & $87.0-113.8$ \\
\hline \multirow[t]{2}{*}{ Testosterone } & 2016 & $30-100$ & 30 & 0.9999 & $1.82-6.74$ & $94.0-99.6$ \\
\hline & 2017 & 50-100 & 50 & 0.9999 & $4.0-7.8$ & $60.7-105.2$ \\
\hline \multirow[t]{2}{*}{ Trimetoprim } & 2016 & 1-100 & 1 & 0.9998 & $0.94-9.10$ & 93.9-111.5 \\
\hline & 2017 & $1-100$ & 1 & 0.9990 & $2.19-7.29$ & $86.0-116.7$ \\
\hline
\end{tabular}

${ }^{1)}$ Range of linearity - range of the analytical method in which the output signal is proportional to the analyte being determined.

${ }^{2} \mathrm{MQL}$ - method quantification limit; the lowest concentration of the substance possible to quantify by a given analytical method with assumed precision and accuracy.

${ }^{3} \mathrm{R}$ - correlation coefficient; a statistical measure that characterises linearity and defines the relationship between test results and concentrations of the substance.

${ }^{4}$ RSD - relative standard deviation; a statistical measure that defines the dispersion of a data set relative to its mean.

${ }^{5}$ Recovery - part of the substance recovered from the sample tested, determined on the basis of measurements of the substance in enriched and non-enriched samples. 
was done in the same way for both analytical methods. A known amount of the analyte mixture at concentrations of $1-100 \mathrm{ng} / \mathrm{dm}^{3}$ was added to tap water samples with a conductivity similar to the samples tested, then subjected to extraction and instrumental analysis similar to the analysis of groundwater samples. Based on the results, metrological parameters of analytical methods were calculated (Table 1). Method quantification limits (MQL) differed from 1 to $50 \mathrm{ng} / \mathrm{dm}^{3}$, and were lower for the high-performance liquid chromatography technique coupled with tandem mass spectrometry (LC-MS/MS). The highest MQL limits concerned testosterone in GC/ MS (SIM) technology and amounted to 30-50 ng/ $\mathrm{dm}^{3}$, and enrofloxacin and caffeine in LC-MS/MS (MRM) technology to $5 \mathrm{ng} / \mathrm{dm}^{3}$.

\section{Results}

\subsection{Detection of pharmaceuticals}

Pharmaceuticals were detected at 85 locations, which amounts to 53 per cent of all sampling points. In total, 24 out of 34 analytes that were included in the 2-year study were detected in water samples. The following ten substances were not detected in any sample: nadolol, atenolol, pindolol, terbutaline, doxepine, imipramine, clomipramine, amitriptyline, sulfachloropiridazine and trimethoprim (Table 2, Fig. 1). The most commonly seen substance was carbamazepine, which was found in a total of 33 monitored locations (21 per cent of all boreholes samples). Carbamazepine is an anti-

Table 2. Number of positive detections and maximum concentrations of specific pharmaceuticals analysed in the present study

\begin{tabular}{|c|c|c|c|c|c|}
\hline No. & Pharmaceuticals & $\begin{array}{c}\text { No. of sites } \\
\text { with detection }\end{array}$ & $\begin{array}{l}\text { No. of sites with de- } \\
\text { tection below MQL }\end{array}$ & $\begin{array}{l}\text { No. of sites with de- } \\
\text { tection above MQL }\end{array}$ & $\begin{array}{l}\text { Maximum concen- } \\
\text { tration }\left(\mathrm{ng} / \mathrm{dm}^{3}\right)\end{array}$ \\
\hline 1 & Estrone & 3 & 0 & 3 & 69 \\
\hline 2 & Estriol & 1 & 0 & 1 & 5 \\
\hline 3 & 17a-etynyloestradiol (EE2) & 2 & 0 & 2 & 61 \\
\hline 4 & 17a-etynyloestradiol (EE2) & 1 & 0 & 1 & 10 \\
\hline 5 & Testosterone & 2 & 2 & 0 & \\
\hline 6 & Nadolol & 0 & & & \\
\hline 7 & Atenolol & 0 & & & \\
\hline 8 & Metoprolol & 1 & 0 & 1 & 5 \\
\hline 9 & Pindolol & 0 & & & \\
\hline 10 & Propranolol & 3 & 1 & 2 & 28 \\
\hline 11 & Terbutaline & 0 & & & \\
\hline 12 & Salbutamol & 1 & 1 & 0 & \\
\hline 13 & Diclofenac & 9 & 3 & 6 & 42 \\
\hline 14 & Ibuprofen & 19 & 10 & 9 & 599 \\
\hline 15 & Ketoprofen & 5 & 0 & 5 & 27 \\
\hline 16 & Naproxen & 4 & 2 & 2 & 40 \\
\hline 17 & Paracetamol & 4 & 2 & 2 & 52 \\
\hline 18 & Flurbiprofen & 7 & 5 & 2 & 22 \\
\hline 19 & Doxepine & 0 & & & \\
\hline 20 & Imipramine & 0 & & & \\
\hline 21 & Clomipramine & 0 & & & \\
\hline 22 & Amitryptyline & 0 & & & \\
\hline 23 & Caffeine & 1 & 0 & 1 & 641 \\
\hline 24 & Carbamazepine & 33 & 0 & 33 & 869 \\
\hline 25 & Sulfadiazine & 5 & 0 & 5 & 28 \\
\hline 26 & Sulfadimethoxine & 10 & 4 & 6 & 6 \\
\hline 27 & Sulfachloropiridazine & 0 & & & \\
\hline 28 & Sulfamerazine & 4 & 0 & 4 & 105 \\
\hline 29 & Sulfamethazine & 5 & 3 & 2 & 31 \\
\hline 30 & Sulfamethoxazole & 20 & 0 & 20 & 66 \\
\hline 31 & Sulfapyridine & 7 & 2 & 5 & 23 \\
\hline 32 & Sulfathiazole & 1 & 0 & 1 & 2 \\
\hline 33 & Enrofloxacin & 14 & 10 & 4 & 7 \\
\hline 34 & Trimethoprim & 0 & & & \\
\hline
\end{tabular}




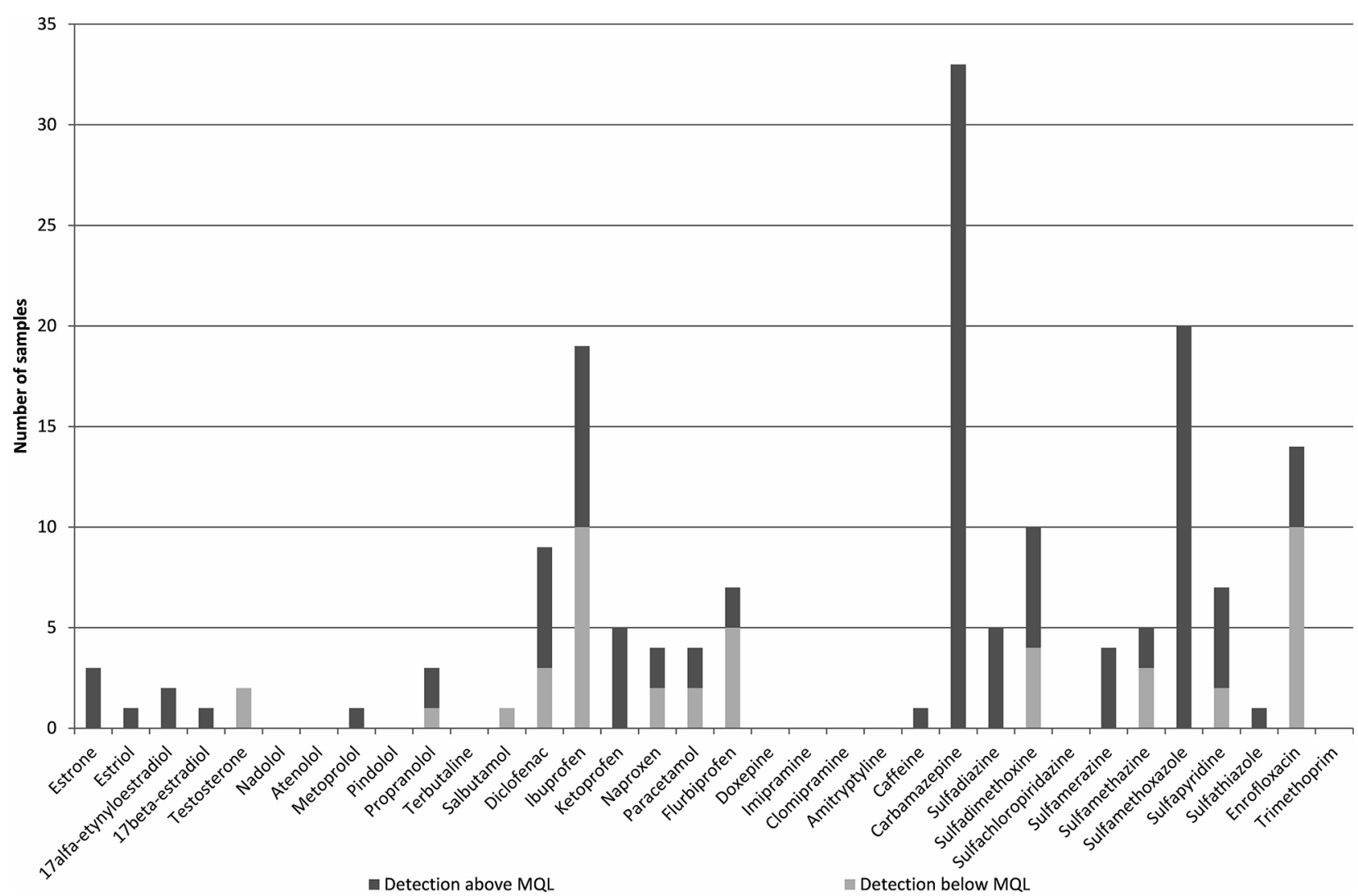

Fig. 1. Distribution of pharmaceuticals in water samples collected for the present study in 2016 and 2017

convulsant medication used primarily in the treatment of epilepsy and neuropathic pain. It is also used to treat schizophrenia and bipolar disorder. It is very mobile and persistent and therefore often found in groundwater (Lapworth et al., 2012; Lopez et al., 2015; Lapworth et al., 2019). All concentrations detected during the present study were quantified and varied from 1 to $869 \mathrm{ng} / \mathrm{dm}^{3}$. The highest value was found in a shallow borehole drilled in Quaternary sands in a small town east of Warsaw. Other studies have reported maximum concentrations in groundwater varying from c. 99 to $900 \mathrm{ng} / \mathrm{dm}^{3}$ (Sacher et al., 2001; Focazio et al., 2008; Lapworth et al., 2012). The second most commonly found substance was the human and veterinary antibiotic sulfamethoxazole. Sulfamethoxazole results in high concentrations in urine, hence is a good indicator of sewage. The substance was found in 20 sampling locations (13 per cent) with concentrations varying between 1 and $66 \mathrm{ng} / \mathrm{dm}^{3}$. The highest concentration was found in a shallow borehole screened in sands in a touristic/rural area in northern Poland. Sulfamethoxazole was also the second most commonly found pharmaceutical reported in Lapworth's review of 2012 (Lapworth et al., 2012), where it was reported at a maximum of $1,100 \mathrm{ng} / \mathrm{dm}^{3}$. Lopez et al. (2015) noted sulfameth- oxazole to be the most frequently quantified antibiotic in France. The pain relief and anti-inflammatory drug ibuprofen was the third most commonly found drug that was detected in 19 locations (12 per cent); however, in 10 of these concentrations were found to be too low to quantify (i.e., marked as below method quantification limit). Quantifiable concentrations varied between 5 and $599 \mathrm{ng} / \mathrm{dm}^{3}$. Ibuprofen was also the third most commonly found pharmaceutical reported by Lapworth et al. (2012), who noted maximum concentrations of $12,000 \mathrm{ng} /$ $\mathrm{dm}^{3}$. In the USA maximum concentrations were reported at 3,110 $\mathrm{ng} / \mathrm{dm}^{3}$ (Barnes et al., 2008). Sacher et al. (2001) also looked for ibuprofen in Germany, but did not report any positive findings. The veterinary antibiotic enrofloxacin was found in 14 sampling locations, which accounts for nine per cent of all sampling locations; however, at only 4 locations concentrations were found at quantitative levels and these varied between 5 and $7 \mathrm{ng} / \mathrm{dm}^{3}$. This antibiotic was also studied by Barnes et al. (2008) in the USA, but not detected. Another veterinary antibiotic, sulfadimethoxine, was found in 10 locations (6 per cent). Quantified concentrations were detected in 6 of these, varying between 1 and 6 $\mathrm{ng} / \mathrm{dm}^{3}$. Sulfadimethoxine was also studied in the USA by Barnes et al. (2008), but not detected. Di- 
clofenac was the second most common drug, after ibuprofen, of the group of analgesics and anti-inflammatory drugs. It was detected in nine sampled locations; in three samples concentrations were at levels below MQL. Concentrations varied from 5 to $42 \mathrm{ng} / \mathrm{dm}^{3}$. Lapworth et al. $(2012,2019)$ reported maximum concentrations of $590 \mathrm{ng} / \mathrm{dm}^{3}$ and also found diclofenac to be the second most commonly analysedpharmaceutical in groundwater across Europe, albeit with low detection rates. Flurbiprofen and sulfapyridine are the last pharmaceuticals among the drugs that were found at more than five sampling points. Flurbiprofen is a non-steroid, anti-inflammatory drug commonly used for treatment of rheumatoid problems. It was detected at seven sampling locations (4 per cent) and concentrations were quantified in two of them ranging between 5 and $22 \mathrm{ng} / \mathrm{dm}^{3}$. Sulfapyridine is a human antibiotic. It was detected at seven sites, at five of which it was quantified at concentrations ranging from 1 to $23 \mathrm{ng} / \mathrm{dm}^{3}$. All other drugs were found at a maximum of five locations.

\subsection{Distribution of pharmaceuticals in relation to land use}

All sampling locations were categorised with respect to land use based on the most recent information from CORINE Land Cover system (2018) and information provided by field technicians. To simplify categorisation of land use types, sampling points were assigned to five land use classes, namely: forests, meadows, industrial and dense urban areas, agricultural areas (villages and crop fields) and urban areas with scattered buildings. Sampling locations located in meadows and forests were usually associated with foresters' buildings or other touristic premises of occasional usageand agro-tourism. This study was aimed at sites with high potential for documentation of pharmaceuticals due to land use and construction of sampling boreholes. Statistics demonstrated a high potential for the presence of pharmaceuticals at all types of land use (Table 3). However, the land use type that proved to be the most prone to pollution with pharmaceuticals are agricultural areas. This is the type of use that was also most extensively covered by the present study. Fifty-two per cent of all sampling sites were located in rural areas and 55 per cent of them showed positive detection of pharmaceuticals. This is due mainly to poor sewage management in rural areas, often based on septic tanks and use of trickled systems, as well as manure distribution as part of agricultural practice. A similar situation was found in urban areas with scattered buildings. Fifty-nine per cent of all sites located in this land use type were proved to be polluted with pharmaceuticals. Sampling locations in meadows and forests were separated from agricultural use and are located in places where pressure from agriculture is considered low; yet, results showed that they are also subjected to pollution from anthropogenic sources.

The distribution of specific types of drugs at different land use type is presented in Table 4 . The highest number of different drugs (21 substances) was found in agricultural areas. The most commonly detected drugs here were sulfametoxazole (an antibiotic for human and veterinary use alike), ibuprofen and carbamazepine. They were found at 17, 16 and 13 per cent of sites, respectively. Other, less common drugs found are sulfadimetoxine (10 per cent of sites) and enrofloxacin (8 per cent of sites), which are both veterinary antibiotics. In urban areas with scattered buildings a total of 20 different substances were found, which is similar to what was found in samples from agricultural lands. However, the distribution of specific pharmaceuticals is different. The pharmaceutical of the highest occurrence in urban areas is carbamazepine, which was found in 34 per cent of samples. In agricultural areas carbamazepine was found in only 13 per cent of samples. The second most common drug in urban areas is diclofenac, which was found in 10 per cent of sites. In agricultural areas the most common pain killer and anti-inflammatory drug was ibuprofen, which was found in 16 per cent of sampling points

Table 3. Distribution of sites with positive detection of pharmaceuticals among different land use types at monitoring sites

\begin{tabular}{|c|c|c|c|c|}
\hline \multirow{2}{*}{$\begin{array}{l}\text { Land use type } \\
\text { at the sampling site }\end{array}$} & \multicolumn{2}{|c|}{ Number of sites } & \multirow{2}{*}{$\begin{array}{c}\text { Sites with pharmaceuticals } \\
\text { among the same land use type } \\
\%\end{array}$} & \multirow{2}{*}{$\begin{array}{c}\text { Sites with pharmaceuticals } \\
\text { among all land use types } \\
\%\end{array}$} \\
\hline & - & $\%$ & & \\
\hline Forests & 23 & 14 & 30 & 4 \\
\hline Meadows & 7 & 4 & 57 & 3 \\
\hline Industrial and urban areas (dense) & 6 & 4 & 67 & 3 \\
\hline Agricultural areas & 83 & 52 & 55 & 29 \\
\hline Urban areas with scattered buildings & 41 & 26 & 59 & 15 \\
\hline
\end{tabular}


Table 4. Distribution of pharmaceuticals with respect to land use types at monitoring sites (number of positive detection, percentage of sites with positive detection within a given land use type)

\begin{tabular}{|c|c|c|c|c|c|c|c|c|c|c|}
\hline \multirow[t]{2}{*}{ Pharmaceuticals } & \multicolumn{2}{|c|}{ Forests } & \multicolumn{2}{|c|}{ Meadows } & \multicolumn{2}{|c|}{$\begin{array}{l}\text { Industrial and urban } \\
\text { areas (dense) }\end{array}$} & \multicolumn{2}{|c|}{ Agricultural areas } & \multicolumn{2}{|c|}{$\begin{array}{c}\text { Urban areas with scattered } \\
\text { buildings }\end{array}$} \\
\hline & - & $\%$ & - & $\%$ & - & $\%$ & - & $\%$ & - & $\%$ \\
\hline Estrone & & & & & & & 1 & 1 & 2 & 5 \\
\hline Estriol & & & & & & & & & 1 & 2 \\
\hline 17alfa-etynyloestradiol & & & & & & & 1 & 1 & 1 & 2 \\
\hline 17beta-estradiol & & & & & & & 1 & 1 & & \\
\hline Testosterone & & & & & & & 1 & 1 & 1 & 2 \\
\hline Metoprolol & & & & & & & & & 1 & 2 \\
\hline Propranolol & & & & & & & 1 & 1 & 2 & 5 \\
\hline Salbutamol & & & & & & & 1 & 1 & & \\
\hline Diclofenac & & & 1 & 14 & & & 4 & 5 & 4 & 10 \\
\hline Ibuprofen & & & 1 & 14 & 2 & 33 & 13 & 16 & 3 & 7 \\
\hline Ketoprofen & & & 1 & 14 & & & 3 & 4 & 1 & 2 \\
\hline Naproxen & & & & & & & 3 & 4 & 1 & 2 \\
\hline Paracetamol & & & & & & & 4 & 5 & & \\
\hline Flurbiprofen & 1 & 4 & 1 & 14 & & & 3 & 4 & 2 & 5 \\
\hline Caffeine & & & & & & & & & 1 & 2 \\
\hline Carbamazepine & 4 & 17 & 3 & 43 & 1 & 17 & 11 & 13 & 14 & 34 \\
\hline Sulfadiazine & & & & & & & 4 & 5 & 1 & 2 \\
\hline Sulfadimethoxine & & & & & & & 8 & 10 & 2 & 5 \\
\hline Sulfamerazine & & & & & & & 2 & 2 & 2 & 5 \\
\hline Sulfamethazine & & & & & & & 4 & 5 & 1 & 2 \\
\hline Sulfamethoxazole & 2 & 9 & 1 & 14 & & & 14 & 17 & 3 & 7 \\
\hline Sulfapyridine & & & & & & & 5 & 6 & 2 & 5 \\
\hline Sulfathiazole & & & & & & & 1 & 1 & & \\
\hline Enrofloxacin & 2 & 9 & 1 & 14 & 1 & 17 & 7 & 8 & 3 & 7 \\
\hline
\end{tabular}

of that sampling group. Diclofenac was found only in 5 per cent of samples in agricultural areas.With respect to hormones, these were found at onefold sites and occurred in both agricultural and urban areas. There was definitely a higher detection of sulfonamides and antibiotics in agricultural areas than in urban areas. After summarising the number of positive detections of all antimicrobial agents, these were found at 57 per cent of sites in agricultural areas vs 34 per cent of urban areas and this probably reflects the wider use of veterinary drugs in rural areas.

Carbamazepine, the most commonly found drug during this study, was also found at sites located near meadows, which are also associated with agricultural areas and in forests, which most likely reflects poor sewage management at these sites. At sites classified as meadows there were also single detections of various anti-inflammatory drugs such as diclofenac, ibuprofen, ketoprofen and flurbiprofen and also the veterinary antibiotics sulfametoxazole and enrofloxacin. The two lastnamed were more often found at sites associated with forests.

\section{Conclusions}

The main aim of the present study was to determine whether active substances of pharmaceuticals do indeed pose a risk to groundwater resources in Poland, as suggested by studies in western Europe and the USA. Results of this study confirm the hypothesis that the risk of pollution with pharmaceuticals does exist also in Poland and needs further assessment and perhaps regulations at national level for the sake of future protection of groundwater resources. It needs to be noted; however, that samples were collected only once in each monitoring sites and as such represent temporary concentrations. Their long-term presence, as well as the level of concentrations, need to be confirmed by repetitive, systematic sampling. The problem seems to be most relevant in rural areas, but urban planning with scattered building is nearly equally threatened by the problem. The distribution of active substances found during the present study with respect to land use at sampling locations indicates communal waste water sources to be the most probable sources of pollution with pharmaceuticals. 


\section{Acknowledgements}

The present study was financed by statutory funds of the Polish Geological Institute - National Research Institute received from the Ministry of Science and Higher Education. Sampling was undertaken during monitoring activities commissioned by the Chief Inspectorate of Environmental Protection and the National Water Management Board and funded by the National Fund for Environmental Protection and Water Management.

\section{References}

Barnes, K., Koplin, D., Furlong, E., Zaugg, S., Meyer, M. \& Barber, L., 2008. A national reconnaissance of pharmaceuticals and other organic wastewater contaminants in the United States - I) Groundwater. Science of the Total Environment 402, 192-200.

Borecka, M., Siedlewicz, G., Haliński, Ł., Sikora, K., Pazdro, K., Stepnowski, P. \& Białk-Bielińska, A., 2015. Contamination of the southern Baltic Sea waters by the residues of selected pharmaceuticals: Method development and field studies. Marine Pollution Bulletin $94,62-71$.

Caban, M., Lis, E., Kumirska, J. \& Stepnowski, P., 2015. Determination of pharmaceutical residues in drinking water in Poland using a new SPE-GC-MS(SIM) method based on Speedisk extraction disks and DIMETRIS derivatization. Science of the Total Environment 538, 402-411.

Caban, M., Migowska, N., Stepnowski, P., Kwiatkowski, M. \& Kumirska, J., 2012. Matrix effects and recovery calculations in analyses of pharmaceuticals based on the determination of $\beta$-blockers and $\beta$-agonists in environmental samples. Journal of Chromatography A $1258,117-127$.

Commission Directive 2014/80/EU of 20 June 2014 amending Annex II to Directive 2006/118/EC of the European Parliament and of the Council on the protection of groundwater against pollution and deterioration.

Cordy, C.E., Duran, N.L., Bouwer, H., Rice, R.C., Furlong, E.T., Zaugg, S.D., Meyer, M.T., Barber, L.B. \& Kolpin, D.W., 2004. Do pharmaceuticals, pathogens, and other waste water compounds persist when waste water is used for recharge? Ground Water Monitoring $\mathcal{E}$ Remediation 24, 58-69.

Directive 2000/60/EC of the European Parliament and of the Council of 23 October 2000 establishing a framezork for Community action in the field of water policy.

Focazio, M.J., Kolpin, D.W., Barnes, K., Furlong, W.T., Meyer, M.T., Zaugg, S.D., Barber, L.B. \& Thurman, M.E., 2008. A national reconnaissance for pharmaceuticals and other organic wastewater contaminants in the United States - II) Untreated drinking water sources. Science of the Total Environment 402, 201-216.

Gaffney, V., Almeida, C., Rodrigues, A., Ferreira, E., Benoliel, M. \& Cardoso, V., 2015. Occurrence of phar- maceuticals in a water supply system and related human risk assessment. Water Research 72, 199-208.

Kmiecik, E., Dwornik, M., Tomaszewska, B., Wątor, K. \& Styszko, K., 2017a. Residues of pharmaceuticals in the water - results of preliminary tests. [In:]

$2 \backslash$ textsuperscript\{nd\} PTIM 2017 proceedings book: 2\} textsuperscript \{nd $\}$ international Caparica conference on Pollutant toxic ions \& molecules : November 6\} textsuperscript $\{$ th $\}-9 \backslash$ textsuperscript $\{$ th $\}$

Kmiecik, E., Wątor, K., Dwornik, M. \& Styszko, K., 2017b. Preliminary results of ibuprofen residue determination in water from southern Poland. [In:] IWA $10^{\text {th }}$ Micropol \& Ecohazars Conference, Vienna, Austria.

Kolpin, D., Furlong, E., Meyer, M., Thurman, E., Zaugg, S., Barber, L. \& Buxton, H., 2002. Pharmaceuticals, hormones, and other organic wastewater contaminants in U.S. streams, 1999-2000: Methods, development and national reconnaissance. Environmental Science and Technology 36, 1202-1211.

Kuczyńska, A., 2017. Wyniki pilotażowego badania zawartości substancji czynnych farmaceutyków w wodach podziemnych $\mathrm{w}$ próbkach wody pobranych z krajowej sieci monitoringu wód podziemnych [Results of a pilot study on the assessment of pharmaceuticals in groundwater in samples collected from the national groundwater monitoring network]. Przeglad Geologiczny 65, 1096-1103.

Kuczyńska, A. \& Janica, R., 2017. Analiza wpływu oddziaływania zanieczyszczeń bytowo-komunalnych ze źródeł rozproszonych na jakość wód podziemnych na przykładzie prac zespołu interwencyjnego państwowej służby hydrogeologicznej [Analysis of the influence of sewage from diffuse sources on the groundwater quality, exemplified by research results of the Polish Hydrogeological Survey intervention team]. Przeglad Geologiczny 65, 1312-1318.

Lapworth, D.J., Baran, N., Stuart, M.E. \& Ward, R.S., 2012. Emerging organic contaminants in groundwater: A review of sources, fate and occurrence. Environmental Pollution 163, 287-303.

Lapworth, D.J., Lopez, B., Laabs, V., Kozel, R., Wolter, R., Ward, R., Vargas-Amelin E., Besien, T., Claessens, J. \& Delloye, F., 2019. Developing a groundwater watch list for substances of emerging concern: a European perspective. Environmental Research Letters 14, 035004.

Loos, R., Locoro, G., Comero, S., Contini, S., Schwesig, D., Werres, F., Balsaa, P., Gans, O., Weiss, S., Blaha, L., Bolchi, M. \& Gawlik, B.M., 2010. Pan-European survey on the occurrence of selected polar organic persistent pollutants in ground water. Water Research 44, 4115-4126.

Lopez, B., Ollivier, P., Togola, A., Baran, N. \& Ghestem, J-P., 2015. Screening of French groundwater for regulated and emerging contaminants. Science of the Total Environment 518-519, 562-573.

PN-EN ISO 5667-11:2004P Jakość wody - Pobieranie próbek Część 11: Wytyczne dotyczace pobierania próbek wód podziemnych [Water quality - Sampling - Part 11: Guidelines for groundwater sampling].

Rozporządzenie Rady Ministrów z dnia 18 października 2016 r. w sprawie Planu gospodarowania wodami na obszarze do- 
rzecza Dniestru [Regulation of the Council of Ministers of October 18, 2016 regarding the River Basin Management Plan for the Dniestr river basin]. Dz. U. 2016 poz. 1917.

Rozporządzenie Rady Ministrów z dnia 18 października 2016 r. $w$ sprawie Planu gospodarowania wodami na obszarze dorzecza Dunaju [Regulation of the Council of Ministers of October 18, 2016 regarding a River Basin Management Plan for the Danube River Basin]. Dz. U. 2016 poz. 1918.

Rozporządzenie Rady Ministrów z dnia 18 października 2016 r. w sprawie Planu gospodarowania wodami na obszarze dorzecza Jarft [Regulation of the Council of Ministers of October 18, 2016 regarding the River Basin Management Plan for the Jarft river basin]. Dz. U. 2016 poz. 1919.

Rozporządzenie Rady Ministrów z dnia 18 października 2016 r. $w$ sprawie Planu gospodarowania wodami na obszarze dorzecza Łaby [Regulation of the Council of Ministers of October 18, 2016 regarding the River Basin Management Plan for the Eaba river basin]. Dz. U. 2016 poz. 1929.

Rozporzadzenie Rady Ministrów z dnia 18 października 2016 r. w sprawie Planu gospodarowania wodami na obszarze dorzecza Niemna [Regulation of the Council of Ministers of October 18, 2016 regarding the River Basin Management Plan for the Niemen river basin]. Dz. U. 2016 poz. 1915.

Rozporządzenie Rady Ministrów z dnia 18 października 2016 r. w sprawie Planu gospodarowania wodami na obszarze dorzecza Odry [Regulation of the Council of Ministers of October 18, 2016 regarding the River Basin Management Plan for the Odra river basin]. Dz. U. 2016 poz. 1967.

Rozporządzenie Rady Ministrów z dnia 18 października 2016 r. w sprawie Planu gospodarowania wodami na obszarze dorzecza Pregoty [Regulation of the Council of Ministers of October 18, 2016 regarding the River Basin Management Plan for the Pregota river basin]. Dz. U. 2016 poz. 1959.

Rozporządzenie Rady Ministrów z dnia 18 października 2016 r. w sprawie Planu gospodarowania wodami na obszarze dorzecza Świeżej [Regulation of the Council of Ministers of October 18, 2016 regarding the River Basin Management Plan for the Świeża river basin]. Dz. U. 2016 poz. 1914.

Rozporządzenie Rady Ministrów z dnia 18 października 2016 r. w sprawie Planu gospodarowania wodami na obszarze do- rzecza Ücker [Regulation of the Council of Ministers of October 18, 2016 regarding the River Basin Management Plan for the Ücker river basin]. Dz. U. 2016 poz. 1818.

Rozporzadzenie Rady Ministrów z dnia 28 listopada 2016 r. $w$ sprawie Planu gospodarowania wodami na obszarze dorzecza Wisty [Regulation of the Council of Ministers of October 18, 2016 regarding the River Basin Management Plan for the Vistula river basin]. Dz. U. 2016 poz. 1911.

Sacher, F., Lange, F., Brauch, H.-J. \& Blankenhorn, I., 2001. Pharmaceuticals in groundwaters. Analytical methods and results of a monitoring program in Baden-Württemberg, Germany. Journal of Chromatography $A$ 938, 199-210.

Seiler, R.L., Zaugg, S.D., Thomas, J.M. \& Howcroft, D.L., 1999. Caffeine and pharmaceuticals as indicators of waste-water contamination in wells. Ground Water 37, 405-410.

Stuart, M., Lapworth, D., Crane, E. \& Hart, A., 2012. Review of risk from potential emerging contaminants in UK groundwater. Science of the Total Environment 416, 1-21.

Verstraeten, I.M., Fetterman, G.S., Meyer, M.T., Bullen, T. \& Sebree, S.K., 2005. Use of tracers and isotopes to evaluate vulnerability of water in domestic wells to septic waste. Ground Water Monitoring \& Remediation 25, 107-117.

Vulliet, E., Cren-Olive, C., 2011. Screening of pharmaceuticals and hormones at the regional scale, in surface and groundwaters intended to human consumption. Environmental Pollution 159, 29-34.

Zuccato, S., Castiglioni, S., Bagnati, R., Chiabrando, C., Grassi, P. \& Fanelli, R., 2008. Illicit drugs, a novel group of environmental contaminants. Water Resources 42, 961-968.

Manuscript received: 9 April 2019

Revision accepted: 28 October 2019 